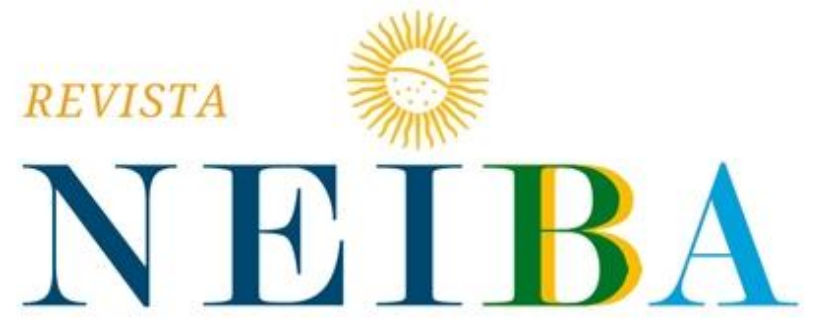

CADERNOS ARGENTINA-BRASIL

\title{
SHALE GAS IN SOUTH AMERICA. FROM THE UNITED STATES' ENERGY SECURITY TO THE PROMISES OF A REGIONAL BOOM
}

SHALE GAS EN AMÉRICA DEL SUR. DE LA SEGURIDAD ENERGÉTICA NORTEAMERICANA A LAS PROMESAS DE UN BOOM REGIONAL

\section{Noemí Soledad Rabbia ${ }^{1}$}

${ }^{1}$ Universidad Nacional de Rosario (UNR), Rosario, Santa Fe, Argentina. E-mail: picoclon@hotmail.com ORCID: https://orcid.org/0000-0001-6078-7632.

Recebido em: 28 ago. 2019 | Aceito em: 20 mar. 2020. 


\section{ABSTRACT}

Even though oil continues leading energy discussions worldwide the share of natural gas in total energy is expected to equal that of oil by 2030. The United States (US) has played a key role in that transition: in the last two decades a qualitative technological leap forward has driven this country to an energy revival through the exploration and production of unconventional gas and oil.

Since its independence Latin America has been considered the United States'backyard with notorious emphasis in Central American and Caribbean countries. However, the increasing energy potential that others Latin American countries like Argentina and Brazil have turned to posses in the unconventional hydrocarbons industry have led to a renewed interest in the region beyond its traditional partners.

The aim of this paper is to explore what could be the interest for the US in shale developments in South America; which are the countries with more potential in developing shale gas industries based on their reserves and above ground factors; and which is the current state of the foreseen South American shale revolution.

Keywords: Shale gas; energy; South America; energy security.

\section{RESUMEN}

Pese a que el petróleo continúa liderando los debates energéticos en todo el mundo, se espera que para el 2030 la participación del gas en el total energético mundial lo iguale. Estados Unidos ha jugado un rol fundamental en dicha transición: en las últimas dos décadas un salto tecnológico cualitativo ha llevado al país a un resurgimiento energético a través de la exploración y producción de gas y petróleo no convencional.

Desde su independencia, América Latina ha sido considerada el "patio trasero de Estados Unidos", con especial énfasis en los países centroamericanos y caribeños. No obstante, el creciente potencial energético que otros países de la región como Argentina y Brasil han resultado tener en relación a la industria de hidrocarburos no 
convencionales ha conllevado un renovado interés norteamericano más allá de sus socios tradicionales en la región.

El objetivo del presente trabajo es explorar cuál sería el interés de Estados Unidos en el desarrollo de la industria del shale en Sudamérica; cuáles son los países de esta subregión con mayor potencial para el desarrollo de shale gas en base a sus reservas y factores por encima del suelo (above ground factors); y cuál es el estado actual de la anunciada "revolución del shale en Sudamérica".

Palabras Claves: Shale gas; energía; América del Sur; seguridad energética.

\section{INTRODUCTION: ENERGY, A MATTER OF NATIONAL SECURITY}

According to Buzan, Waever and De Wilde (1998) security refers to the survival of a designated referent object which has been presented as existentially threatened. In this sense, whether there is or not agreement on the validity of the securitization of energy, the issue has occupied a significant position as a matter of national security in most governmental agendas since 1973, when the first international oil crisis took place. In its pursuit, western powers have devoted great deal of its policies to the creation of systems, regimes or critical infrastructure, among others, to enhance their perception of safety in energy realms.

Although energy as a statesmen's concern can be traced to the early 20th century its most popular definition is credited to Daniel Yergin (2011) as the availability of sufficient energy supply at affordable prices; the concept has gained more complexity following the lead of more complex societies and realities.

For the United States of America (US) securing resources became even more important after the collapse of the Soviet Union not only as a key contributor to the nation' survival but also as a powerful leverage in word politics, a central piece for the continuity of its relevance in shaping a new world order and sustaining its role within it.

Even though oil continues leading energy discussions worldwide the share of natural gas in total energy is expected to equal that of oil by 2030 (BP, 2013, p. 18). In 2017, natural gas accounted for the largest increment in energy consumption followed 
by the renewables and then oil (BP, 2018, p. 1). The US played a key role in that transition: in the last two decades a qualitative technological leap forward has driven the US to an energy revival through the exploration and production of unconventional gas and oil; a period generally defined as the shale revolution.

For decades geologists generally believed that hydrocarbon resources could be extracted only if they had migrated to the reservoir rock, where there were interconnected pore spaces through which the oil and gas could flow. If you drill a well into the reservoir rock the pressure underground can send the oil and gas flowing up to the surface. Traditionally, if you drilled a well into shale, you were wasting your time. Advances in two technologies in the late 1990s and early 2000s changed all that, although at first only for gas (Crooks, 2015).

When shale gas became commercial at the beginning of this century triggered a transforming process of the world energy geopolitics which started with the potential, and then real, transition of the US to become a net exporter of natural gas. As a consequence of that, once again, the country's foreign agenda and how the US relates with other regions and countries were reshaped.

Since its independence Latin America has been considered the US's backyard, with notorious emphasis in Central American and the Caribbean countries. However, the increasing energy potential that others Latin American countries, like Argentina and Brazil, have turned to posses in the last decade has led to a renewed interest in the region beyond its traditional partners.

\begin{tabular}{|c|c|c|c|}
\hline \multicolumn{4}{|c|}{ Table 1: Top 10 countries with technically recoverable shale gas } \\
\hline Rank & Country & Estimated recoverable resources $\left(\mathrm{TcF}^{1}\right)$ & $\begin{array}{c}\text { Date } \\
\text { of information }\end{array}$ \\
\hline
\end{tabular}

\footnotetext{
${ }^{1}$ This abbreviation stands for Trillion Cubic Feet.

${ }^{2} \mathrm{~A}$ resource assessment is used to assess the resources or skills that exist among the people or communities with which you hope to work. It provides an understanding of the quantity, quality, and geologic distribution of world oil and gas resources. They are conducted in an impartial manner and are performed in collaboration and partnership with energy experts within and outside governments. Through synthesis and improved understanding of global oil and gas data, they seek to establish a geologic basis for predicting energy production trends. Until date, the EIA/ARI World Shale Gas and Shale Oil Resource Assessment (2013) has remained undisputed.
} 


\begin{tabular}{|c|c|c|c|}
\hline & & & \\
\hline 1 & China & 1,115 & 2013 \\
\hline 2 & Argentina & 802 & 2013 \\
\hline 3 & Algeria & 707 & 2013 \\
\hline 4 & US & 665 & 2013 \\
\hline 5 & Canada & 573 & 2013 \\
\hline 6 & Mexico & 545 & 2013 \\
\hline 7 & Australia & 437 & 2013 \\
\hline 8 & South Africa & 390 & 2013 \\
\hline 9 & Russia & 285 & 2013 \\
\hline 10 & Brazil & 245 & 2013 \\
\hline- & Rest of the & 1,535 & Source: EIA (2019) \\
\hline & World & & \\
\hline
\end{tabular}

While the US may be, if not the only, the most successful case of significant volumes of shale gas production and commercialization, it is not the only country in the region with sizeable reserves. In 2013 the US Energy Information Administration (EIA) and the US Department of Energy released a report - the "World Shale Gas and Shale Oil Resource Assessment 2013" - assessing promising shale basins around world. Within Latin America, Southern countries -particularly Argentina- appeared holding the second biggest reserve of non-conventional gas in the world (802 Tcf). A Latin American shale revolution -replicating the North American success- was foreseen.

In spite of this initial optimism the US shale boom has not been replicated in the region so far: beyond resources assessments, above ground factors like a robust service sector, technological innovation, land access facilitated by private ownership, favourable fiscal and regulatory terms (BP, 2013, p. 23-24), direct investment, cost of production, safety and political stability continue to be challenging. 
Bearing this information in mind, the aim of this paper is to explore what could be the interest for the US in shale developments in South America; which are the countries with more potential in developing shale gas industries based on their reserves and above ground factors; and which is the current state of the foreseen South American shale revolution.

This work claims that the US interest in a South American shale revolution is lead by its advantages in the sector (mostly technology and expertise), the pursuit of control over the shale energy market's future and the externalization of the negative impacts, mainly land and water pollution, associated to the use of fracking. I also claim that in the short term a combination of below and above ground factors constraint the occurrence of a shale revolution in the Southern part of Latin America. Finally, for the case of the country with the biggest potential due to the size of its shale gas reserves Argentina- the lack of political stability will continue to prevent the generation of a business environment that contributes to the replication of the US success in the shale gas sector.

Existing literature on shale gas industry's prospects in South America include resources assessments produced by governments and official institutions (US EIA, 2011 and 2013; European Commission, 2017; EIA, 2017) mainly in the Western Hemisphere; papers and articles issued by the industrial practitioners of shale gas exploitation and entities directly involved in its development like the BP Annual Statistical Review of World Energy; and, the media reports like in Arthur (2014); Begos (2012); Loki (2016); Mander (2019); and Mendoza (2019).

Most of our claims have been already addressed by Mares (2012); Bercovich and Rebossio (2015); Bianchi (2015); Gomez Jr. (2014); and Bindon (2017), among others. However, in the academic field the topic continues to be relatively new, especially in South America where studies have been produced with focus in each country separately and often isolated from the US interest in the region's developments.

This paper is a descriptive/analytical report which has used different sources including data available in open sources, news from the media, official reports and literature on this topic, mainly in English, Spanish and Portuguese. 


\section{SHALE REVOLUTION: HOW AND WHERE IT ALL BEGAN}

"Large-scale natural gas production from shale began around 2000, when shale gas production became a commercial reality in the Barnett Shale located in Texas. The production of Barnett Shale natural gas was pioneered by the Mitchell Energy and Development Corporation" (EIA, 2017) starting in the 1980s. [...] By 2000, the company had developed a hydraulic fracturing technique that produced commercial volumes of shale gas. As the commercial success of the Barnett Shale became apparent, other companies started drilling wells in this formation and continue its expansion to other regions in the US.

Since then shale gas production in the US has risen by more than a $1000 \%$ between 2006 and 2018 (Graphic 1); as a result between 2012 and 2014, according to US EIA estimates, US petroleum and natural gas production first surpassed Russia and became the world's top producer of natural gas and oil. Currently, "global gas production is led by the US and Middle East (Qatar and Iran) - who together account for almost 50\% of the growth in gas production" (BP, 2019, p. 95).

Furthermore until 2000 the US exported relatively small volumes of natural gas and mostly by pipeline to Mexico and Canada.

\footnotetext{
"Total annual exports have generally increased each year since 2000 as increases in US natural gas production contributed to lower natural gas prices and improved the competitiveness of US natural gas in international markets. In 2018, the United States exported natural gas to 33 countries".
}

Total annual imports of natural gas have declined since 2007; total annual imports peaked in 2007 at about 5 Tcf (EIA, 2017).

In political realms this has helped to create a stronger leverage in bilateral relations with countries like Iran, Russia or Venezuela; it has also integrated government strategies to bolster the industry and its expansion nationally and worldwide. 


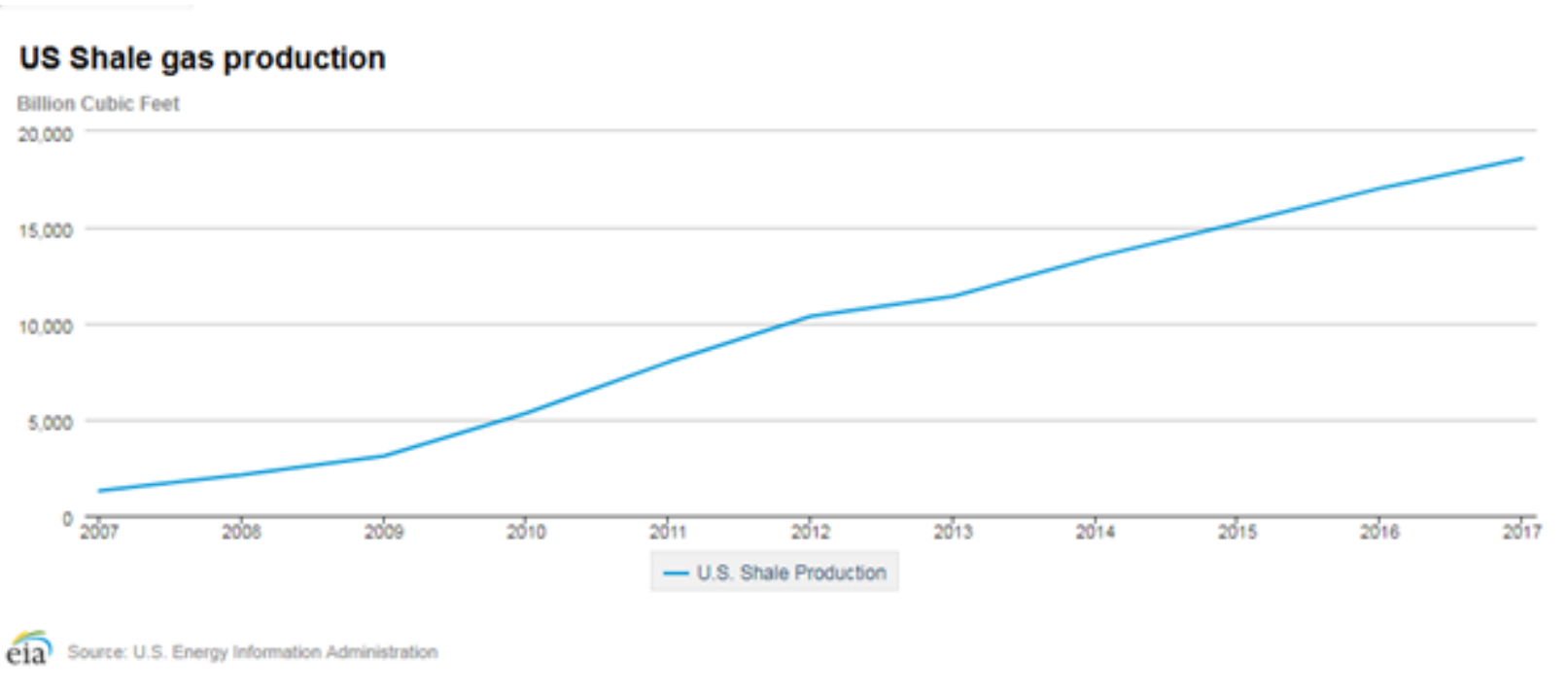

\section{TO FRACK OR NOT TO FRACK}

In spite of the economic and energy security success in the US, the extensive use of fracking has provoked concerns about the direct and indirect impact of the technique with especial focus on environment. "Hydraulic fracturing, or fracking as it is better known, is a method of extracting oil and gas trapped in shale and other rock formations" (Vaughan, 2018); currently, it involves pumping large amounts of water down a well at high pressure, along with sand and chemicals that fracture the rock and release the gas or oil, which flows to the surface.

Along the last decade has found as many detractors as supporters; as Vaughan (2018) states for the case of the United Kingdom (UK), governments and enterprises involved in the business have repeatedly said that fracking can be done safely and without harming the environment or human health, so long as it is properly regulated. However, even though new rules mean that companies have to closely monitor and report seismic activity, as well as potential water and air pollution, has not been the case throughout fracking's history, particularly when it grew rapidly in the US.

As mentioned above, fracking uses enormous amounts of water, which must be transported to the site at significant environmental cost. As well environmentalists say potentially carcinogenic chemicals may escape during drilling and contaminate groundwater around the fracking site (BBC, 2018). A years-long research by the US 
Environmental Protection Agency (EPA) concluded in 2016 that in some cases fracking had harmed drinking water supplies. Some of the impacts mentioned include:

\begin{abstract}
"water withdrawals for hydraulic fracturing in times or areas of low water availability; spills during the management of hydraulic fracturing fluids and chemicals or produced water that result in large volumes or high concentrations of chemicals reaching groundwater resources; injection of hydraulic fracturing fluids into wells with inadequate mechanical integrity, allowing gases or liquids to move to groundwater resources; injection of hydraulic fracturing fluids directly into groundwater resources; discharge of inadequately treated wastewater to surface water resources; and disposal or storage of wastewater in unlined pits, resulting in contamination of groundwater resources" (p. 45-46).
\end{abstract}

There has been also concern about fracking-related earthquakes and critics have also implied worrisome including industrialisation of rural areas, noise from lorries and air pollution derived from flaring, when excess gas is burned off (Kreuze, Norman and Schelly, 2016).

Outside the US, where no broad production has been made, public opinion is also skeptical of fracking, especially in the European Union (EU) where there are environmental concerns and remaining doubts on how it would impact on communities; the main apprehension is related to a higher average population density than in the US which does not minimize pollution's impacts on population.

\footnotetext{
"For several years, Europe was talked up as a new frontier for shale exploration. Poland was seen as one of the most promising prospects, attracting US companies such as Chevron, ConocoPhillips and Exxon, as Warsaw hoped to ease its reliance on Russian gas. But the geology did not prove as promising as hoped and, one by one, companies pulled out. A similar pattern occurred in Romania. Other European countries have gone further and banned fracking: France, Germany and Ireland have all imposed moratoriums ${ }^{3 \prime \prime}$ (Vaughan, 2018).
}

Australia -a country which is estimated to contain 429 Tcf of shale gas- is another example of the debate about fracking which is dividing the country; "fracking policies vary widely across Australia's states and territories, and so do community attitudes and [there is] an inconsistent approach in how governments have responded to the industry" (Schalit, 2018).

\footnotetext{
${ }^{3} \mathrm{~A}$ waiting period set by an authority.
} 
Similar debates are being made in South America; as in the rest of the world, there is still no agreement on the negative impacts of the shale industry especially in cases like Argentina, where exists greater economic motivations to expect and promote a shale boom.

\title{
THE SOUTH AMERICAN SHALE DREAM
}

While the existence and recoverability of shale resources in South America is apparent (Table 2)

\begin{abstract}
"the economic viability of extracting them is [still] unclear, given production costs, volumes, and wellhead prices. Beyond purely economic considerations, a variety of factors including the regulatory framework, infrastructure, access to capital, and environmental and other political considerations could potentially retard development of the sector, especially as the pace of shale gas development quickens and investors concentrate elsewhere" (Gómez Jr., 2014, p. 3).
\end{abstract}

\begin{tabular}{|c|c|c|c|}
\hline \multicolumn{4}{|c|}{ Table 2: Countries with technically recoverable shale gas } \\
in South America \\
\hline Country & Shale gas & Shale oil & Last Update \\
\hline $\begin{array}{c}\text { United } \\
\text { States }\end{array}$ & 622.5 & 78.2 & $4 / 14 / 15$ \\
\hline Argentina & 801.5 & 27.0 & $5 / 17 / 13$ \\
\hline Brazil & 244.9 & 5.3 & $5 / 17 / 13$ \\
\hline Venezuela & 167.3 & 13.4 & $5 / 17 / 13$ \\
\hline Paraguay & 75.3 & 3.7 & $5 / 17 / 13$ \\
\hline Colombia & 54.7 & 6.8 & $5 / 17 / 13$ \\
\hline Chile & 48.5 & 2.3 & $5 / 17 / 13$ \\
\hline Bolivia & 36.4 & 0.6 & $5 / 17 / 13$ \\
\hline Uruguay & 4.6 & 0.6 & $5 / 17 / 13$ \\
\hline & & & Source: EIA (2019) \\
\hline
\end{tabular}

A key challenge among these countries in order to duplicate the US experience are property rights: while in the US the fracking boom has largely been private-sector 
triggered, in South America the State owns lands rights and issues development permits. The other obstacles have to be addressed case by case, as it follows.

\section{ARGENTINA}

Outside US and in South America, Argentina contains the most sizeable recoverable reserves of shale gas; moreover Argentina has the most advanced shale industry in the region with hundred of wells drilled and numerous projects in production compared to its neighbors. This activity is primarily located within the Neuquén Basin which contains the Los Molles and Vaca Muerta shale formations, with Vaca Muerta considered to be one of the premier shale gas areas in South America if not the world.

In addition Argentina's location in the Southern Atlantic Ocean Basin offers access to demand from the US but especially from Asia. For instance,

\footnotetext{
“China doesn't have much tight oil, but it has far and away the world's largest reserves of shale gas, and it has strong reasons to want to develop them, both in terms of pursuing greater energy security (and reducing reliance on energy imports), and also in order to reduce the amount of coal it burns for electricity and heat-and all of the toxic smog that that entails. [...] For Beijing, water scarcity and the remote locations of its shale regions will compound the problems that many other countries face (like a lack of mineral rights and a dearth of fracking expertise)" (The American Interest, 2017).
}

Water availability and a much lower average population density than in the US are other two key factors when it comes to asses Argentina' shale industry advantages. In spite of that, after 8 years the initial optimism Argentina has not become a commercial production boom yet. In 2014 over 20,000 horizontal wells were expected to be drilled in the US compared with 250 in Argentina during the same time period. And currently, while in the US there would be an estimated number of 1,182,278 shale wells (oil and gas) (Fractracker, 2017) Argentina has 660, twice it had in 2014 but still far from the foreseen boom.

Expectations have proved to be much higher than results; one of the main reasons is the lack of enough investments and capital; persisting distrust among investors is derived from historical economic and political instability in the country. In addition, investors demand further market reforms such as price controls and moderate labor 
unions. Also additional infrastructure should be developed in order to make Vaca Muerta more competitive.

According to the World Bank Group's Doing Business 2019 report Argentina ranked 119 out of a sample of 190 countries, right after The Bahamas and above Egypt. Out of ten indicators Argentina performed far from the media in five of them: Starting business (128); Dealing with construction permits (174); Trading across borders (125); Enforcing contracts (107) and Paying taxes (169).

In spite of the government change in 2015 and Mauricio Macri's promises of reform many of them did not come true due to domestic economic and political constraints. Some estimations address that USD 10 billions annually in investments are required for developing shale industry in Argentina; in 2018 they reached USD 3 billions, which is a fine number but not enough closed to meet expectations.

\footnotetext{
"Daniel Gerold, at G \& G Energy Consultants in Buenos Aires, says companies will now start to invest more in shale oil, which is much simpler to export than natural gas - not least because, for now, Argentina lacks the gas pipelines and liquefaction plants that would make exporting over long distances possible" (Mander, 2018).
}

In 2017 the Argentina's Ministry of Energy and Mining published Resolution 46E/2017 which created a program to stimulate investments in natural gas production projects in the Neuquén Basin's unconventional reservoirs. The Program guarantees minimum prices for gas from unconventional reservoirs sold in the domestic market, starting in 2018 for a period of four years.

Designed to boost gas output in Vaca Muerta, the government committed to paying gas producers the difference between the sale price and $\$ 7.50$ per million BTU (British thermal unit), falling each year to $\$ 6$ by 2021 when the programme ends (Mander, 2018). In other words, the resolution approved subsidized generation of liquid gas by paying a higher price than the market for the fuel resulting from new investment projects.

As a consequence there was an increase in the number of companies, such as the state oil company YPF, France's Total, PanAmerican Energy, exploiting areas which gained the official authorization to start operating and expected to receive subsidies 
(Straccia, 2019). The government response to such promises were affected first by an accelerated depreciation of the national currency during 2018 and second for the Letter of Intent signed with IMF in October that year in order to achieve a substantial decrease in its primary fiscal deficit.

Additional uncertainty was derived from the results of the general election held in October which led to a victory of the Peronista Party's nominees, Fernandez-Fernandez, including the former President Cristina F. Kirchner as Vice President Candidate. During her eight-year term that ended in 2015, Mrs. Kirchner nationalized the National Oil Company (YPF), implemented price controls and defaulted on Argentina's debt.

Last but not least, there are land conflicts involving the indigenous people, mainly the Mapuche community. The Mapuche community has become increasingly antagonistic reclaiming what they describe as their ancestral lands throughout Patagonia. Their activism has resulted in repeated confrontations with law enforcement which in August 2017 resulted in the disappearance and death of activist Santiago Maldonado and in November, in a police shooting of a young Mapuche protestor, Rafael Nahuel, outside Bariloche, both cases bringing renewed attention to the conflict (Gedan, 2018).

BRAZIL

Despite the fact that Brazil is the country with the second most sizeable recoverable reserves of shale gas in South America -226 Tfc- the sector has not taken off yet and it seems it might not do it any time soon. It is true that among the challenges for operating in the country are ageing infrastructure, corruption scandals, political instability, organized crime expansion and the emerging impacts of climate change, among others. However, they do not have as much incidence on shale prospects as the country abundant conventional resources and the significant share of renewable energy in the Brazilian energy matrix.

In 2000 the discovery of large oil reserves in the offshore Pre-Salt layer changed Brazil's role in the world energy geopolitics. Few years later, the Pre-Salt fields' exploration and production of conventional oil and gas allowed the country to start becoming an oil net exporter: from 750 thousands barrels per day in 2007 Brazil is 
currently producing more than 2.5 millions of barrels per day while its consumption rounds 3 millions; the Pre-Salt fields respond for about $48 \%$ of the national oil production.

Regarding the renewable sector, it is expected to continue to grow and play a vital role in the county's energy mix. Even though it faces challenges for its expansion, currently hydropower is a well-developed energy sector; onshore wind power capacity is expanding and biofuel production is already used extensively in the transport and industrial sectors ${ }^{4}$.

The importance of natural gas in the country's overall energy mix is also growing and there have been official announcements of interest in exploring Brazil's gas potential, including its unconventional gas resources. The country

"has considerable reserves of shale gas in the states of Paraná and Mato
Grosso, two large producers of soya beans. The production of fertilizers in
loco could provide an opportunity for developing this industry close to its end
users, and at the same time promote some energy efficiency gains in terms
of transport (currently most fertilizers are produced in the Southeast region,
and need to be transported inland)" (Growth Analysis, 2014, p.18).

However, in spite of the State's interest in promoting the shale industry auctions in the last years, investors have shown little or none interest (Growth Analysis, 2014, p. 13). Due to the Pre-Salt's profitability no commercial development has been made in the sector; most of the gas available in the country is associated to (conventional) oil and if this is not enough for supplying domestic markets imports would be preferred due to existing infrastructure in the North and South East of the country. Last June 2019, Argentina exported its first Liquefied Natural Gas (LNG) shipment from Bahia Blanca to Brazil. Additionally, Brazil Senate is discussing for the first time a law project in order to ban fracking, after Parana became the first state in the country to prohibit the technique.

In sum, the Brazilian energy sector faces a strategic moment, with a number of challenges and opportunities being presented to policy and decision-makers, but it seem not to be pointing to the shale sector as long as there are more affordable, cheaper and more accessible energy options on the horizon.

\footnotetext{
${ }^{4}$ Brazil is the world's second largest producer of ethanol fuel.
} 


\section{OTHER CONTRIES}

Outside Argentina and Brazil, the remaining countries have technically recoverable shale gas reserves mainly below the 70 Tcf; despite that compared to the other two cases discussed their shale potential may seem irrelevant, each country presents particularities which help to shed some light on the actual prospects of the shale gas industry in those countries.

Venezuela, Paraguay, Chile, and Bolivia possess 167, 75, 48 and 36 Tcf respectively; in the four cases the main challenge to the shale industry is the fact that there exist more competitive energy substitutes or industries which make preferable to focus on them instead of pursuing the exploration/exploitation of shale resources: conventional oil in Venezuela, copper in Chile (Torres, 2015), hydropower in Paraguay (Velazques and Mitjans Amarilla, 2018) and conventional gas in Bolivia ${ }^{5}$ (Del Granado Cosio, 2018).

Additionally, Chile's location between Argentina and Bolivia and existing gas import/export infrastructure to north and south have made extremely difficult to promote local shale industry and attracting investors due to the lack of relative competitive advantage.

Paraguay faces a similar situation due to its vicinity with Argentina; also lack of infrastructure and political instability can be added as supplementary obstacles for the shale industry development scenarios. In the case of Venezuela, a volatile economic and political context creates also extra reluctance for investors.

Even when Uruguay does not hold comparable reserves to its neighbors there has been some interest shown by the government in promoting shale developments. However, after more than 5 years of the first assessment made by the US EIA, little progress has been achieved.

Colombian state's aims to promote shale exploitation have been similar to the case of Uruguay; however, in spite of the initial optimism the industry stills faces skepticism and legal obstacles since the Supreme Court suspended legal frame on fracking passed by Ministerial Order in March 2014 (Resolution n. 90341/March 24). There is also worrisome on security realms due to the atomization of threats coming from multiple

\footnotetext{
${ }^{5}$ In August 2019 YOFB (the national energy company) signed an agreement for the exploration of shale resources with the Canadian company Cancambia Energy.
} 
violent actors filling the vacuum left by the FARC (Revolutionary Armed Forces of Colombia for its acronym in Spanish) in the vicinities of the extractive sites.

Among these countries, Chile and Uruguay would be considered to have a more stable regulatory environment combined with the country's openness to investment and security, which are encouraging conditions seem not to be sufficient to encourage exploration and exploitation commercially.

\section{US, FRACKING AND SOUTH AMERICA}

The continue growth of its gas production driven by shale industry has given the US "a comparative advantage in the sector. The development of techniques such as hydraulic fracturing and horizontal drilling, among others, provided the catalyst for rapid development in the United States" (Gomez Jr., 2014, p.3). Several factors paved the way: inexpensive access to basins, subsoil rights given to property owners rather than to the State, a suitable and enforceable contract law and "a decentralized and difficult to revise regulatory context that has limited the impact of environmental concerns on shale exploration and production" (Mares, 2012, p.4). Such conditions and the resulting success derived in an accumulation of technology, capital, and managerial expertise which is critical for new developments outside the shale revolution's homeland and put the US and its shale private sector in a privileged position in the development of shale gas resources outside North America through technology transfer and training, infrastructure, and workforce development. This vision has been materialized over the last decade in a series of initiatives by the US governments.

In April 2009 US President Barack Obama launched the Energy and Climate Partnership of the Americas (ECPA) at the Summit of the Americas. The ECPA was allegedly conceived as a flexible mechanism to accelerate sustainable energy in the Americas and built upon seven pillars including renewable energy, energy efficiency, energy poverty, cleaner and more efficient use of fossil fuels, infrastructure, sustainable land use and forestry, and adaptation. A year later the US Department of State launched the Global Shale Gas Initiative (GSGI) as part of an effort to promote global energy security and climate security around the world. In that occasion, the Secretary of State, Hillary Clinton stated: 


\begin{abstract}
"the United States will promote the use of shale gas. Now, I know that in some places is controversial. But natural gas is the cleanest fossil fuel available for power generation today, and a number of countries in the Americas may have shale gas resources. If developed, shale gas could make an important contribution to our region's energy supply, just as it does now for the United States" (2010).
\end{abstract}

Countries were selected to participate in GSGI based on the known presence of natural gas-bearing shale within their borders, market potential, business climates, geopolitical synergies, and host government interest (ECPA, 2019). South American countries that participate in GSGI include Argentina, Chile, Colombia, Peru, and Uruguay.

"The GSGI uses government-to-government policy engagement to bring the US federal and state governments' technical expertise, regulatory experience and diplomatic capabilities to help selected countries understand their shale gas potential" (ECPA, 2019). Programs are tailored to each country's specific needs and availability of funding, and activities can include shale gas resource assessments, guidance on appropriate regulatory policies and fiscal structures challenges, as well as invitations to conferences, meetings, training and public-private sector events in the US.

In spite of unmistakable official efforts to promote the industry outside the US, in 2016, before the New York primary's election, Hillary Clinton's campaign aired a commercial on upstate television stations touting her work as secretary of state forcing "China, India, some of the world's worst polluters" to make "real change." She promised to "stand firm with New Yorkers opposing fracking, giving communities the right to say 'no.'” (Fang, 2016). Later on, Wikileaks -an international non-profit organisation that publishes news leaks, and classified media provided by anonymous sources- released hacked emails from the account of Hillary Clinton's campaign boss, John Podesta. The emails revealed efforts by Clinton and her close aides to export American-style hydraulic fracturing to countries all over the world which suggested that the State Department officials worked closely with private sector oil and gas companies, pressed other agencies within the Obama administration to commit federal government resources including technical assistance for locating shale reserves, and distributed agreements with partner nations pledging to help secure investments for new fracking 
projects. It was revealed that at least 13 different government agencies were part of the efforts to export the US shale boom.

Currently President Donald Trump threats to limit US overseas investment in order to bring jobs back to the country, slap tariffs on imports, roll back energy sector regulations, and renege on Washington's international climate change commitments have create additional frictions with Latin American countries overall which could also have an impact on shale gas investors in the region. "As Trump looks to incentivize companies to invest domestically, the United States' investment overseas may shrink (O'Connor and Viscidi, 2017)". For the case of Argentina, this can be particularly challenging due to ideological and political differences between the two countries.

\section{CLOSING REMARKS}

The shale oil and gas have become relevant sources of energy in the last years due to the advance of technology which has increased the possibilities for diversification of supply beyond conventional hydrocarbons. They have also impacted world politics, first due to the renewed leverage given to the US as main holder of the expertise and technology associated to this industry; and secondly, due to its worldwide distribution which is more spread than conventional oil and gas, which are mainly held in big quantities in few regions.

It also could be said that in spite of its significance, shale gas exploration and extraction outside the US in general, and South America in particular, still resembles far from the boom experienced in the former at the beginning of this century. For the case of South America the initial optimism -which foresaw an unconventional energy revolution in 2011 and 2013- has been replaced for more cautious prospects in order to set more feasible goals which vary depending on specific factors from case to case.

Even though below ground factors (recoverable reserves) show great potential for the occurrence of a South American shale revolution, especially in the case of Argentina and Brazil, in the short term it continues to be challenged by risks -which in turn increase cost of initial investments- associated to political instability, legal and economic uncertainty -especially in Argentina- and more affordable and accessible 
energy substitutes -like conventional oil and gas and renewable energy in the case of Brazil.

As mentioned above, the most promising reserves are located in Argentina, where elections held in October -with the Peronista party's victory- creating greater uncertainty. The size of its reserves and domestic market, its existing infrastructure, expertise (derived from conventional hydrocarbon industry) and demography are certainly advantages but still they do not have enough weight to dissipate uncertainty for foreign investors; a national strategic plan may mitigate historical records of legal insecurity in order to incentivize greater amounts of foreign investments required for a further expansion of production; some progress has be done in the last 3 years but certainly not at the pace expected.

Conflict in loco is also on the rise: whether is scientific consensus or not on the environmental impact of shale industry, skepticism (in part inherited from the conventional hydrocarbons exploitation) persists mainly related to pollution of water and soil and mismanagement of wastewater not only in Argentina but also in Brazil, Uruguay and Paraguay. In Colombia there is also criticism but the debate between the national government and those against fracking is focused on tight oil rather than shale gas.

Outside Argentina and Brazil -who has not shown interest in the shale industry so far- there is a combination of below and above ground factors that constraints the occurrence of a shale revolution. To the smaller sizeable reserves factors like an adverse public opinion towards fracking -Colombia, Uruguay-; a deficient infrastructure and lack of technology and expertise -Paraguay-; investors distrust and political instability Paraguay, Venezuela- and increasing security concerns -Colombia, Paraguay- can be added. Argentina's proximity and the increasing Bolivian production of conventional gas are other two factors which reduce their competitiveness and prospects of shale developments at least in the short term.

North America continues to be the shale industry most successful case worldwide; this leverage offers the opportunity and increases the interest on securing resources beyond the US borders in order to enhance its energy security while reducing 
environmental costs and controversy raised by public opinion against the technique. Initiatives launched by the US governments -along with the emails revealed by the 2016 Wikileaks scandal involving Hillary Clinton- acknowledge such goal and show that when it comes to pursuit the replication of the US shale boom political and economic interests are intertwined.

In spite of who the US would prefer to associate with in South America, as the above mentioned assessments prove, currently Argentina holds the most sizeable shale gas reserves and has official interest in a full scale shale development based not only in its bellow ground advantages but also the country's hydrocarbon expertise and the lack of any other comparable energy industry to rely on. However, with a change of government in Argentina as a possibility ahead, which may have ideological discrepancies with Donald Trump's administration; additional uncertainty should be expected in the short term.

Further studies should be develop in order to explore the relation between the size of recoverable reserves, governmental interest in the industry and the anti-fracking sentiment which already exists in Argentina but is relatively localized in the environmentally most affected areas in the Southern region.

\section{BIBLIOGAPHY}

Arthur, A. (2014). "Shale Oil and Gas the Latest Energy Frontier for South America," Oilprice.com. June 5. <https://oilprice.com/Energy/Energy-General/Shale-oil-and-gasthe-latest-energy-frontier-for-South-America.html> Accessed: July 27, 2019.

BBC (2018). "What is fracking and why is it controversial?" October, 15. <https://www.bbc.com/news/uk-14432401> Accessed: July 27, 2019.

Begos, K. (2012). "Fracking Developed With Decades of Government Investment". Associated Press. September 23. $<$ https://energyindependenceforstates.wordpress.com/2012/09/30/frackingdeveloped-with-decades-of-government-investment/> Accessed: July 29, 2019.

Bercovich, A; Rebossio, A. (2015). Vaca Muerta. 1a ed. Buenos Aires: Planeta.

Bianchi, A. (2015). Argentina Saudita. 1a ed. Buenos Aires: Sudamericana.

Bindon, M. (2017). MBA Thesis. "Los recursos no convencionales en Argentina: lineamientos para su desarrollo sustentable tomando en consideración el caso norteamericano". Universidad Torcuato Di Tella. 
<https://repositorio.utdt.edu/bitstream/handle/utdt/11135/MBA_2017_Bindon.pdf?se quence=1\&isAllowed=y> Accessed: July 29, 2019.

British Petroleum (BP) (2013). “BP Energy Outlook 2030". January. $<$ https://www.bp.com/content/dam/bp/business-

sites/en/global/corporate/pdfs/energy-economics/energy-outlook/bp-energy-outlook2013.pdf> Accessed: July 30, 2019.

(2019). "BP Energy Outlook 2019 edition".

$<$ https://www.bp.com/content/dam/bp/business-

sites/en/global/corporate/pdfs/energy-economics/energy-outlook/bp-energy-outlook2019.pdf> Accessed: July 27, 2019.

Buzan, B.; Waever, O.; Wilde, J.d. (1998). Security: A new framework for analysis. Boulder: Lynne Rienner Pub. pp. 21-49.

Crooks, E. (2015). "The US shale revolution". Financial Times. <https://www.ft.com/content/2ded7416-e930-11e4-a71a-00144feab7de.> Accessed: July 25, 2019.

Del Granado Cosio, H. (2018). "Shale gas en Bolivia y el mundo". Los tiempos. $<$ https://www.lostiempos.com/actualidad/opinion/20180222/columna/shale-gas-

bolivia-mundo> Accessed: August 13, 2019.

Energy and Climate Partnership of The Americas (ECPA) 2019. <http://www.ecpamericas.org/initiatives/?id=28 > Accessed: August 13, 2019.

European Commission (2017). "Resource estimation of shale gas and shale oil in Europe". Report. February. < https://ec.europa.eu/jrc/sites/jrcsh/files/t7_resource_estimation_of_shale_gas_and_sh ale_oil_in_europe.pdf> Accessed: August 13, 2019.

Fang, L; Horn, S. (2016). “Hillary Clinton's Energy Initiative Pressed Countries to Embrace Fracking, New Emails Reveal" The Intercept. May 23. <https://theintercept.com/2016/05/23/hillary-clinton-fracking/> Accessed: August 13, 2019.

Fractracker (2017). "34 states have active oil \& gas activity in U.S. based on 2016 analysis". <https://www.fractracker.org/2017/03/34-states-active-drilling-2016/> Accessed: July 29, 2019.

Gedan, B; Phalen, C. (2018). "Argentina's Shale Energy Plans Run into Trouble" Americas Quarterly. February 13. <https://www.americasquarterly.org/content/argentinas-shaleenergy-plans-run-trouble> Accessed: July 29, 2019.

Gómez Jr., C. (2014). "Shale gas development in Latin America" Americas Society and Council of the Americas. <http://www.as-coa.org/articles/shale-gas-development-latinamerica> Accessed: July 29, 2019. 
Kreuze, A.; Norman, E.; Schelly, C. (2016). "To frack or not to frack: Perceptions of the risks and opportunities of high-volume hydraulic fracturing in the United States". <http://www.emmanorman.net/publications_159_3582432106.pdf> Accessed: August 1, 2019.

Loki, R. (2016). "Hillary Clinton Tried to Push Fracking on Other Nations When She Was Secretary of State, New Emails Reveal" May 25. $<$ https://www.alternet.org/2016/05/hillary-clinton-tried-push-fracking-other-nationswhen-she-was-secretary-state-new/> Accessed: August 13, 2019.

Mander, B. (2018). "Argentina's Vaca Muerta shale oil and gas offers tough lessons". Financial Times. September 23. < https://www.ft.com/content/75e6d166-90f5-11e89609-3d3b945e78cf> Accessed: August 6, 2019.

Mander, B. (2019). "Argentina seeks to replicate success of US shale boom". August 6. Financial Times. <https://www.ft.com/content/579cf542-afa7-11e9-8030530adfa879c2> Accessed: August 6, 2019.

Mares, D. (2012). "The new energy landscape". Inter-American Development Bank. Discussion $\quad$ paper. N. IDB-DP-253. <https://publications.iadb.org/en/publication/11799/new-energy-landscape-shale-gaslatin-america> Accessed: August 1, 2019.

Mendoza, N. (2019). "Fracking in Colombia: For Real This Time?" Americas Quarterly March 21. < https://www.americasquarterly.org/content/fracking-colombia-real-time> Accessed: August 13, 2019.

Ministry of energy and mining of Argentina (2017). Resolution 46-E/2017. March 2. < https://www.boletinoficial.gob.ar/detalleAviso/primera/174878/20171117> Accessed: July 27, 2019.

Ministry of energy and mining of Colombia (2014). Resolution n. 90341/March 24. < https://www.icbf.gov.co/cargues/avance/docs/resolucion_minminas_90341_2014.htm > Accessed: July 27, 2019.

O'Connor, R; Viscidi, L. (2017). "Trump and Latin American Energy. The cost of cutting ties" Foreign Affairs. February 24 <https://www.foreignaffairs.com/articles/centralamerica-caribbean/2017-02-24/trump-and-latin-american-energy> Accessed: August 13, 2019.

Schalit, N. (2018). "Fracking policies are wildly inconsistent across Australia, from gunghodevelopment to total bans". December 3. Available: http://theconversation.com/fracking-policies-are-wildly-inconsistent-across-australiafrom-gung-ho-development-to-total-bans-108039. Accessed: July 25, 2019.

Straccia, J. (2019). “Government's adjustment plan for Vaca Muerta puts conflict on the horizon". February $2 . \quad$ BA $\quad$ Times. $<$ https://www.batimes.com.ar/news/economy/governments-adjustment-plan-for-vacamuerta-puts-conflict-on-the-horizon.phtml> Accessed: July 25, 2019. 
Swedish agency for growth policy analysis (Growth Analysis) (2014). "Energy Policy in Brazil".

https://www.tillvaxtanalys.se/download/18.201965214d8715afd113b87/14325487401

27/Energisystem+bortom+2020+Brasilien.pdf > Accessed: August 12, 2019.

The American Interest (2017). "The State of Global Shale". September 6. < https://www.the-american-interest.com/2017/09/06/state-global-shale/> Accessed: July 28, 2019.

US Energy Information Administration (EIA) (2011). "World Shale Gas Resources: An Initial Assessment of 14 regions outside the US". <http://www.madalenaenergy.com/download/ARI\%20EIA\%20Intl\%20Gas\%20Shale\%20 APR\%202011\%20select.pdf> Accessed: July 25, 2019.

(2017). "The United States now produces nearly all of the natural gas that it uses". <https://www.eia.gov/energyexplained/index.php?page=natural_gas_where> Accessed: July 25, 2019.

US Energy Information Administration / US Department of Energy (2013). "EIA/ARI World Shale Gas and Shale Oil Resource Assessment". <https://www.advres.com/pdf/A_EIA_ARI_2013\%20World\%20Shale\%20Gas\%20and\%20Shale\%200il\%20 Resource\%20Assessment.pdf> Accessed: July 25, 2019.

US Environmental Protection Agency (2016). "Hydraulic Fracturing For Oil And Gas: Impacts From The Hydraulic Fracturing Water Cycle On Drinking Water Resources In The United States" (Final Report). U.S. Environmental Protection Agency, Washington, DC, EPA/600/R-16/236F.

<https://cfpub.epa.gov/ncea/hfstudy/recordisplay.cfm?deid=332990> Accessed: August 5, 2019.

Vaughan, A. (2018). "Fracking - the reality, the risks and what the future holds". February $26 . \quad$ The Guardian. <https://www.theguardian.com/news/2018/feb/26/fracking-the-reality-the-risks-andwhat-the-future-holds> Accessed: August 5, 2019.

Velázquez Ibarrola, C; Mitjans Amarilla, F. (2018). "Potential of Unconventional Hydrocarbons in the Paraguayan Chaco: Carandayty Sub-Basin Case" IOSR Journal of Environmental Science, Toxicology and Food Technology (IOSR-JESTFT) Volume 12, Issue 7 Ver. II. July. Pp 65-77 < http://iosrjournals.org/iosr-jestft/papers/Vol12\%20lssue\%207/Version-2/J1207026577.pdf> Accessed: August 10, 2019.

Yergin, D. (2011). The Quest: Energy, Security, and the Remaking of the Modern World. Penguin Books. Chapter 13.

World Bank Group (2019). "Doing Business". $<$ https://www.doingbusiness.org/content/dam/doingBusiness/media/AnnualReports/English/DB2019-report_web-version.pdf> Accessed: July 25, 2019. 